Surlyk, F. 1983: Source rock sampling, stratigraphical and sedimentological studies in the Upper Palaeozoic of the Jameson Land basin, East Greenland. Rapp. Grønlands geol. Unders. 115, 88-93.

Surlyk, F., Hurst, J. M., Marcussen, C., Piasecki, S., Rolle, F., Scholle, P. A., Stemmerik, L. \& Thomsen, E. 1984a: Oil geological studies in the Jameson Land basin, East Greenland. Rapp. Grønlands geol. Unders. 120, 85-90.

Surlyk, F., Piasecki, S., Rolle, F., Stemmerik, L., Thomsen, E. \& Wrang, P. 1984b: The Permian Basin of East Greenland. In: Spencer, A. M. et al. (edit.) Petroleum geology of the North European margin. Graham \& Trotman Ltd. for the Norwegian Petroleum Society, 303-315.

Surlyk, F., Frazier, T., Harpøth, O., Hurst, J. M., Piasecki, S., Rolle, F., Scholle, P. A. \& Stemmerik, L.: Lithostratigraphy of the Upper Permian Foldvik Creek Group, East Greenland. Unpublished manuscript 1986.

Sweet, W. C. 1976: Conodonts from the Permian-Triassic boundary beds at Kap Stosch, East Greenland. Meddr Grønland 197(5) Appendix, 51-54.

Teichert, C. \& Kummel, B. 1976: Permian-Triassic boundary in the Kap Stosch area, East Greenland. Meddr Grønland 197(5), $49 \mathrm{pp}$.

Thomsen, E. 1985: A coalification study of Upper Palaeozoic - Mesozoic deposits from central East Greenland. Unpublished Int. Rep. Grønlands geol. Unders. 1-9-1985, Parts I \& II, 54 pp.

Waterhouse, J. B. 1972: The evolution, correlation, and paleogeographic significance of the Permian ammonoid family Cyclolobidae. Lethaia 5, 251-270.

\title{
Glaciological investigations at the margin of the Inland Ice north-east of Jakobshavn, West Greenland
}

\section{Henrik Højmark Thomsen and Niels Reeh}

Glaciological field investigations have been carried out on the Inland Ice north-east of Jakobshavn. The work is a part of the hydropower investigations at Pâkitsoq in a drainage basin proposed for a local hydropower project.

\section{Drainage basin and glaciological setting}

The drainage basin at Pâkitsoq lies between $69^{\circ} 25^{\prime} \mathrm{N}$ to $69^{\circ} 32^{\prime} \mathrm{N}$ and $50^{\circ} 05^{\prime} \mathrm{W}$ to $50^{\circ} 20^{\prime} \mathrm{W}$ (fig 1). Excluding its Inland Ice sector the basin covers an area of $33.6 \mathrm{~km}^{2}$ and is situated at about $200-600 \mathrm{~m}$ a.s.l. The main part of the runoff from the basin is meltwater draining through three lakes, 326, 233 and 187, from the adjoining Inland Ice sector. Lake 187 is proposed as the main reservoir.

The basin contains four outlet glaciers from the Inland Ice (inventory nos 1GE07001-2, 1GE04001-2) and the central one, 1GE07001, terminates in lake 187. The glaciers have retreated since 1880 (Weidick, 1968). The thinning of glacier 1GE07001 between 1880 and 1959 is estimated by photogrammetric methods to be about $40 \mathrm{~m}$ near the margin, decreasing to about $20 \mathrm{~m}$ at $350 \mathrm{~m}$ a.s.l (Thomsen, 1983a). The meltwater from lake 233 to lake 187 


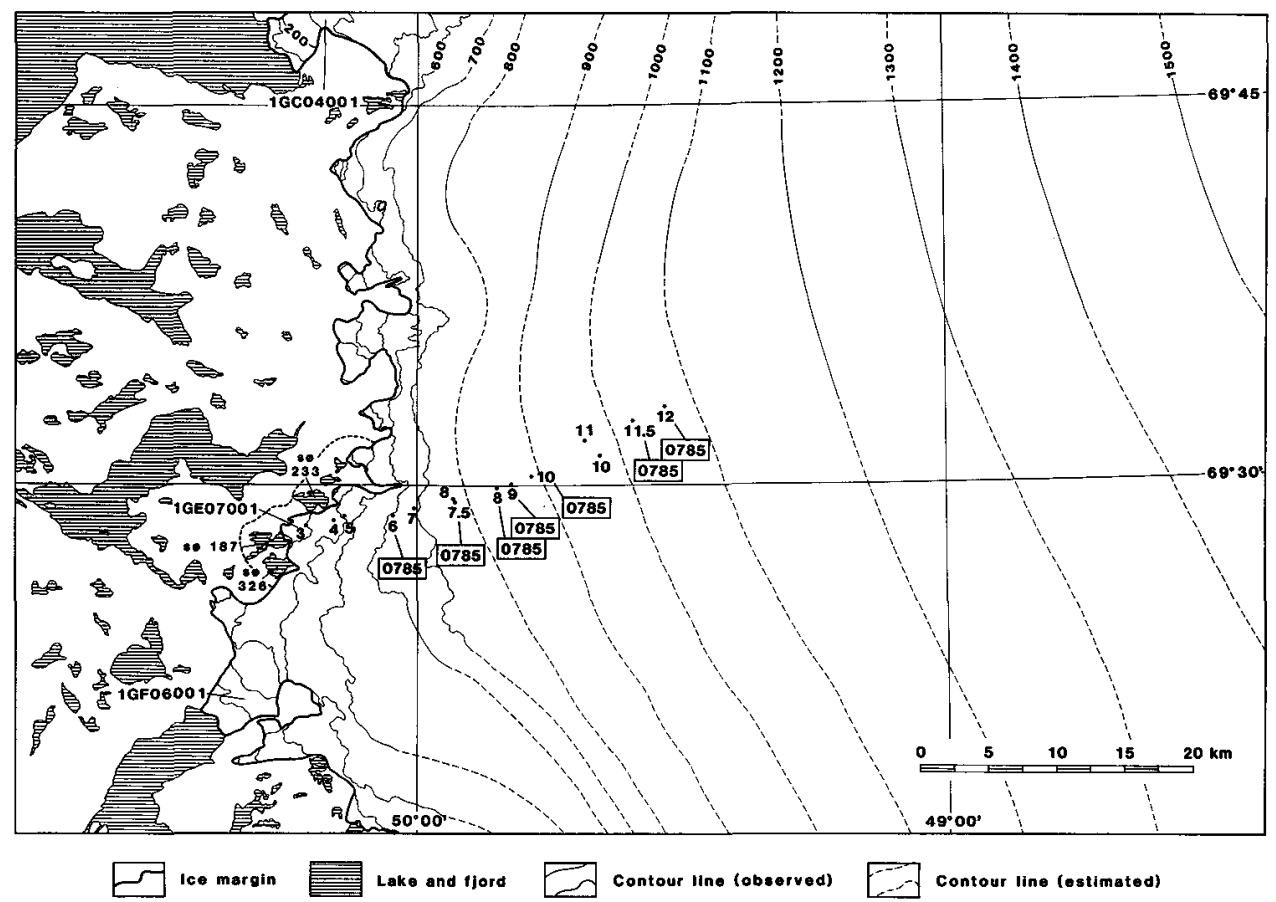

Fig. 1. Drainage basin at Pâkitsoq. Stakes drilled into the ice are shown. Contours in metres. Position of stake 10.0 is estimated as no survey has been carried out.

drains at present along the northern lateral part of glacier 1GE07001. This drainage way was blocked earlier by glacier 1 GE 07001 and the water then drained out of the basin from the westernmost part of lake 233. The change in drainage took place sometime between 1953 and 1959 (Thomsen, 1983a).

Meltwater drainage on the ice itself is complicated. Over large areas meltwater drains through innumerable rivers whose drainage courses are influenced by the surface undulation and different structural features on the ice surface. In many cases the rivers escape down into moulins or crevasses, after which the meltwater drainage is controlled by en- and subglacial drainage conditions.

\section{Glaciological programme}

The glaciological programme was started in August 1982 when stakes for measuring the mass balance were drilled into the ice. Brief reports on the work have been given in Thomsen (1984b, 1985), and a more detailed description can be found in Thomsen (1983a, 1984a).

In response to increasing demands for detailed glacier maps covering the area under investigation, a photogrammetric map was produced (Thomsen, 1983a). The plotting was based on existing vertical aerial photographs from 27th June 1959 covering the outer marginal part of the Inland Ice. The map scale is 1:25 000 with contour intervals of $50 \mathrm{~m}$ in the ice-free 
area and $10 \mathrm{~m}$ on the ice. A similar map is at present under preparation based on new aerial photographs from 16 August 1982.

Special problems appear in connection with delineating hydrological drainage basins on a continuous ice cover like the Inland Ice. Over large areas the drainage basin limits lie within the ice cover itself. Detailed topographic information on large areas, e.g. about ice surface undulations and structural features on the ice, is necessary for an accurate mapping of the surface drainage. Furthermore information about the subglacial topography is required to enable estimation of the en- and subglacial drainage conditions. Digital processing of Landsat data has been used for mapping subtle topographic surface features on the ice reflecting the subglacial topography (Thomsen, 1983b, 1983c). On the basis of Landsat data, hydrological drainage basin sizes have been estimated on the Inland Ice (Thomsen, 1984a). This shows that smaller areas than estimated earlier can be expected (Thomsen, 1983c, 1984a).

Runoff simulations for the area have been carried out using the MB1/SM1/RO1 model developed by GGU (Braithwaite \& Thomsen, 1984). The simulations were based on data from the Danish Meteorological Institute's climate station in Jakobshavn, mass balance data from the area, and the revised drainage area estimates based on Landsat data. The simulated runoff based on the revised drainage basin areas is in better agreement with measured runoff for the area than earlier found.

Glacier dynamic modelling has been applied to the Inland Ice sector between $69^{\circ} 18^{\prime} \mathrm{N}$ and $69^{\circ} 45^{\prime} \mathrm{N}$ (Reeh, 1983). The model calculates the response of the marginal sector to mass balance changes. The calculated response is in agreement with observed ice margin fluctuations. The model has been used to make predictions, and it is concluded that the present ice margin recession will continue for at least some decades, unless a dramatic deterioration of the climate occurs in the near future, leading to conditions similar to those prevailing during the coldest periods of the 'little Ice Age'. Because of a lack of data from the area many quantities must be estimated. Reeh (1983) describes what data should be collected to improve the calculations, e.g. better data on surface topography and ice thickness.

In response to the demand for better subglacial topographic information an electromagnetic reflection programme was set up in 1984 by GGU in co-operation with the Electromagnetics Institute, Technical University of Denmark (Thomsen \& Madsen, 1985). A 300 $\mathrm{mHz}$ ice-radar was mounted in a Twin-Otter fixed wing aircraft. The mission failed, probably due to technical problems with the radar and a too simple antenna arrangement.

\section{Fieldwork 1985}

Mass balance measurements 1984/85. The stakes were visited by helicopter on the 9 th of May, 25th of July and on the 7th of August. There were some difficulties in finding the stakes. In May stake 11.0 was not found. A new stake, stake 4.0 was established. In July stakes 8.0 and 10.0 were not found and stake 11.0 was recovered. Six new stakes (stakes $6.0 /$ $0785,7.5 / 0785,8.0 / 0785,10.0 / 0785,11.0 / 0785$ and 12.0/0785) were established. In August stake 8.0 was recovered. Repeated altimeter readings revealed deviations from the elevations earlier assumed (Thomsen, 1984b, 1985). Generally the stake elevations are lower than first believed. The stake elevations given in Table 1 are the best present estimates based on mean altimeter readings.

The stakes were surveyed in August with microwave line-of-sight, radio-location equipment belonging to the Greenland Technical Organisation (GTO). The work was carried out 
Table 1. Transient balance and annual balance for the Inland Ice at Pakitsoq in millimetres of water

\begin{tabular}{lccccc}
\hline Stake & $\begin{array}{c}\text { Approximate } \\
\text { elevation } \\
\text { m a.s.1. }\end{array}$ & $\begin{array}{c}\text { 24th Aug 84 } \\
\text { 9th May 85 }\end{array}$ & $\begin{array}{c}\text { 9th May 85 } \\
\text { 7th Aug 85 }\end{array}$ & $\begin{array}{c}\text { 25th Jul 85 } \\
\text { 7th Aug 85 }\end{array}$ & $\begin{array}{c}\text { 24th Aug 84 } \\
\text { 7th Aug 85 }\end{array}$ \\
\hline 3.0 & 245 & -482 & -3168 & -513 & -3650 \\
4.0 & 395 & - & -2475 & -423 & - \\
5.0 & 440 & -396 & -2655 & -432 & -3051 \\
$6.0 / 0785$ & 570 & - & - & -279 & - \\
7.0 & 630 & -102 & -1862 & -294 & -1964 \\
$7.5 / 0785$ & 735 & - & - & -270 & - \\
8.0 & 735 & -63 & -1476 & - & -1539 \\
$8.0 / 0785$ & 780 & - & - & -333 & - \\
9.0 & 870 & - & -1619 & -275 & -1616 \\
$10.0 / 0785$ & 910 & - & - & -230 & - \\
10.0 & 970 & 106 & - & - & - \\
11.0 & 995 & - & - & -342 & -1428 \\
$11.5 / 0785$ & 1055 & - & - & -261 & - \\
$12.0 / 0785$ & 1120 & - & - & $-(48)$ & - \\
\hline
\end{tabular}

- Stake not found or not established ( ) Icy firn estimated density $0.6 \mathrm{~g} / \mathrm{cm}^{3}$

in co-operation with Bo Madsen and Søren Holm (GTO). The new stake positions are plotted in fig. 1. Disagreements between stake elevations given in Table 1 and elevations which can be read on the map (fig. 1) are due to the inadequate topographic map base and the errors in the altimeter readings.

The winter snow cover on the ice was very patchy and confined mainly to drifts in gullies and crevasses up to stake 7.0, whereas it was continuous at higher elevations. The transient balance for the winter period was measured in snow pits and by depth soundings at the stakes. As there were no signs of heavy melting during the winter the observed distribution of snow cover is probably due to wind drifting. The transient and annual balances are shown in Table 1. The ablation was high compared with that of earlier years. Compared with the $1983 / 84$ ablation, the $1984 / 85$ ablation was $6.5 \%$ higher at $245 \mathrm{~m}$ a.s.1., although the measuring period 1984/85 was nearly a month shorter.

On the 7th August the surface was still covered with firn at stake 12.0/0785. The firn cover was continuous at higher elevations and the transition between firn covered surface and bare ice was between stake $11.5 / 0785$ and stake $12.0 / 0785$. From these observations the annual equilibrium line was approximately $1100 \mathrm{~m}$ a.s. 1 .

Drainage conditions on the Inland Ice. Surface drainage conditions were studied by reconnaissance on foot and by helicopter. The ice reconnaissance by foot was concentrated just east of lake 326 (fig. 1).

Surface water drains through innumerable small rivers, collecting into big river systems. The rivers often run over long distances on the surface, but the water often escapes down into the ice through crevasses or moulins. Surface drainage is to a high degree dependent on local surface undulations, reflecting subglacial conditions and structural features such as shear bands, healed crevasses and ridges indicating the ice flow pattern. The rivers often run in canyons up to $6 \mathrm{~m}$ deep (fig. 2), cutting through the surface undulations. The river bed in 


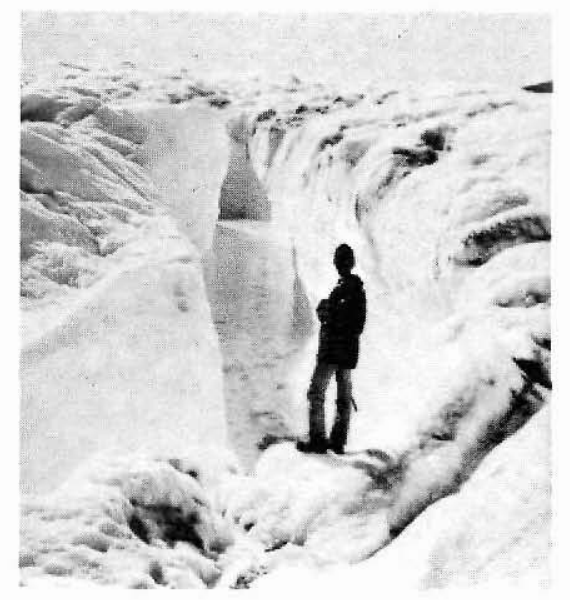

Fig. 2. River system running in canyon on the Inland Ice at Pâkitsoq.

these canyons sometimes inclines inland, opposite the ice surface inclination and directs the meltwater away from the ice margin over varying distances. Such drainage conditions complicate mapping of surface drainage on the basis of ordinary topographic maps.

Reconnaissance along a river system on the ice east of lake 362 showed that for the abovementioned reason less water than expected is draining to the lake.

Many questions arise while studying the surface drainage. The drainage system is not stationary. The rivers adjust to change in water amounts but how and with what speed? Furthermore, the drainage system is developed on a moving medium, the ice. The ice is moving under the drainage system. How fast does a drainage system adjust to changes in ice dynamics? Questions like these are difficult to answer. They require at least detailed observations of drainage conditions over a longer continuous period.

A great number of lakes exist on the ice. During field work it has been observed that some of these lakes empty through the existing drainage system. In many cases no sign of surface drainage is seen on the ice surface, whereas smaller crevasses cutting through the lake bottom can be observed. Lake water temperature controls the ability of the water to make its way through and beneath the ice. Temperature profiles in lakes lying at different elevations on the Inland Ice were measured. The measurements were carried out by a helicopter equipped with floats. The estimated size of the lakes ranged from about $0.1 \times 0.1 \mathrm{~km}$ to about $1 \times$ $1 \mathrm{~km}$ with depths varying from $1.2 \mathrm{~m}$ to $4.2 \mathrm{~m}$. No variation of temperature with depth was found and all lake temperatures were above $0^{\circ} \mathrm{C}$. The temperatures increase with decreasing elevation from $0.1-0.2^{\circ} \mathrm{C}$ at about $1000 \mathrm{~m}$ a.s.l. to $0.8^{\circ} \mathrm{C}$ at about $350 \mathrm{~m}$ a.s.l. (fig. 3). As no obvious relation between water volume in the lake and temperature exists, the above trend can probably be related to length of melting season and the temperature of the underlying ice.

Collection of ice and water samples. As part of a programme for studying stable isotope conditions in the ablation zone of the Inland Ice, ice, snow and water samples have been collected (see Reeh \& Thomsen, this report). The work in the Pâkitsoq area was carried out to test a supposition that stable isotope studies may provide useful data for testing the glacier 


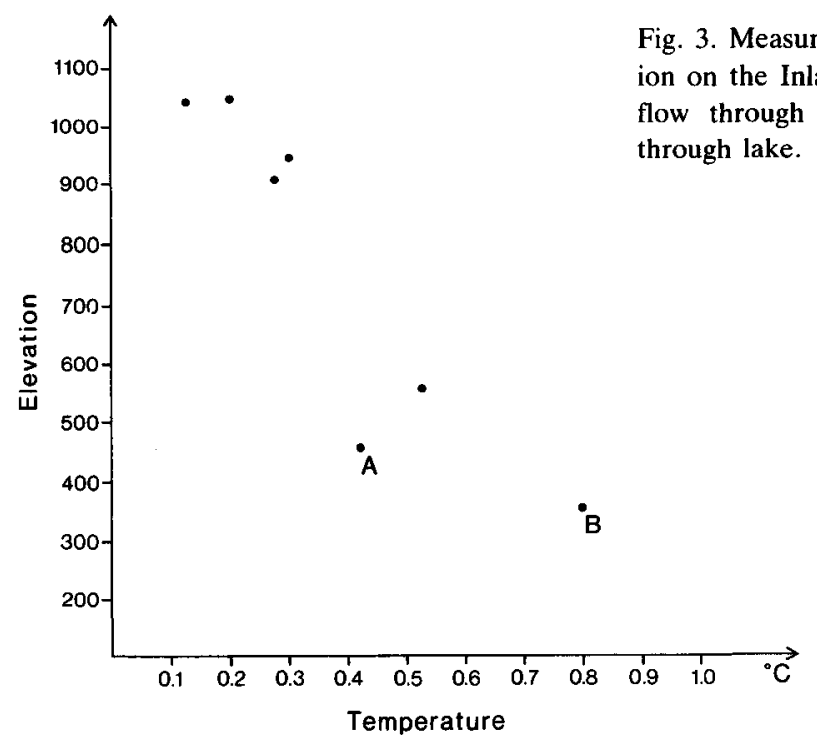

flow model used in the area (Reeh, 1983) and provide information on meltwater drainage conditions.

Electromagnetic reflection. The attempt to use radar for mapping the subglacial topography in the Pâkitsoq area was continued in 1985. In co-operation with the Electromagnetics Institute, Technical University of Denmark, the $300 \mathrm{mHz}$ radar underwent a detailed technical check and a new improved antenna was constructed, designed to be mounted on a Bell 206 Jet Ranger helicopter. The technical check, the improved antenna, and the slow low-altitude flying possible with the helicopter resulted in successful radar mapping this year. The marginal part of the Inland Ice betweeen $69^{\circ} 20^{\prime} \mathrm{N}$ and $69^{\circ} 32^{\prime} \mathrm{N}$ up to an elevation of about 600-700 $\mathrm{m}$ a.s.l. was mapped (see Thorning, Thomsen \& Hansen, this report).

Acknowledgements. The field work was supported by the European Economic Community through the EEC European Development Fund. Bo Madsen and Søren Holm, GTO, helped to survey the stakes.

\section{References}

Braithwaite, R. J. \& Thomsen, H. H. 1984: Runoff conditions at Paakitsup akuliarusersua, Jakobshavn estimated by modelling. Grønlands geol. Unders., Gletscher-hydrol. Meddr 84/3, 22 pp.

Reeh, N. 1983: Ikke-stationær beregningsmodel for Indlandsisens randzone. Grønlands geol. Unders., Gletscher-hydrol. Meddr 83/7, 81 pp.

Thomsen, H. H. 1983a: Glaciologiske undersøgelser ved Pâkitsup ilordlia 1982. Ilulissat/Jakobshavn. Grønlands geol. Unders., Gletscher-hydrol. Meddr 83/3, 24 pp.

Thomsen, H. H. 1983b: Glaciological applications of Landsat images in connection with hydropower investigations in West Greenland. Proc. EARSel/ESA Symposium on Remote Sensing Applications for Environmental Studies. Spec. Publ. Europ. Space Agency 188, 133-136.

Thomsen, H. H. 1983c: Satellitdata - et redskab til studier af Indlandsisens randzone i forbindelse med vandkraftundersøgelser. Grønlands geol. Unders., Gletscher-hydrol. Meddr 83/8, 24 pp. 
Thomsen, H. H. 1984a: Glaciologiske undersøgelser i Disko Bugt området 1983. Grønlands geol. Unders., Gletscher-hydrol. Meddr 83/8, 24 pp.

Thomsen, H. H. 1984b: Glaciological reconnaissance, mass balance measurements and mapping programmes in connection with Greenland hydropower. Rapp. Grønlands geol. Unders. 120, 95-99.

Thomsen, H. H. 1985: Glaciological field work and remote sensing in connection with hydropower investigations, West Greenland. Rapp. Grønlands geol. Unders. 125, 95-99.

Thomsen, H. H. \& Madsen, P. S. 1985: Radio ekko målinger af Indlandsisens randzone i Disko Bugt området 1984. Grønlands geol. Unders., Gletscher-hydrol. Meddr 85/1, 20 pp.

Weidick, A. 1968: Observations on some Holocene glacier fluctuations in West Greenland. Bull. Grønlands geol. Unders. 73 (also Meddr Grønland 165,(6) 202 pp.).

\title{
Stable isotope studies on the Greenland ice-sheet margin
}

\author{
Niels Reeh and Henrik Højmark Thomsen
}

Stable isotope analysis has been used intensively in the investigation of snow and ice-cores retrieved from the central region of the Greenland ice sheet. The $\delta^{18} \mathrm{O}$ records from the deep ice cores drilled at Camp Century and Dye 3, for example, provided detailed climatic information for the past maybe more than 100000 years (Dansgaard et al., 1985). However, although the marginal zone of the ice sheet is readily accessible compared with the central region, little attention has been given to stable isotope studies in the marginal zone (the ablation zone).

\section{Sampling programme}

To provide a background to evaluate stable isotope methods for studying the hydrology and dynamics of the marginal zone of the Greenland ice sheet, a sampling programme was carried out by the authors in the 1985 field season as part of GGU's glacier-hydrological studies in West Greenland. The main efforts were concentrated in the ablation zone at Pâkitsup akuliarusersua about $40 \mathrm{~km}$ north-east of Jakobshavn/Ilulissat (fig. 1), where glacier-hydrological investigations have been carried out by GGU since 1982 (Thomsen, 1983). More than 700 ice and water samples were collected from 13 different locations. The samples comprise winter snow, collected on 9 May at seven sites along the GGU ablation profile covering an elevation interval of $250-900 \mathrm{~m}$, and samples of surface ice and meltwater collected along the same profile during the period $25 \mathrm{July}-7$ August at 12 sites in the elevation range 250 $1100 \mathrm{~m}$. At two locations (elevations 250 and $870 \mathrm{~m}$ ) $2.5 \mathrm{~m}$ ice cores were drilled to see to what extent the original seasonal variation in $\delta{ }^{18} \mathrm{O}$ would still be preserved in the ice of the ablation zone. Further detailed sampling of the surface ice at 2 and $5 \mathrm{~m}$ intervals was performed along a profile transverse to the ice margin south of lake 326 to a distance of $1.2 \mathrm{~km}$ from the ice edge (fig. 1). Moreover, some 100 samples were collected at nine different locations from the margin and drainage basin of Jakobshavn Isbræ with assistance from a field 